\title{
Energy Generation from Anaerobic Treatment of Vegetable Wastes
}

\author{
Dennis E. Ganas and Dr. Consorcio S. Namoco Jr.
}

\begin{abstract}
Market vegetable wastes are regularly dumped to municipal landfills. They harm the environment by producing a greenhouse gas, methane, which is twenty times more potent than carbon dioxide. They form leachate which is highly toxic and can pollute the land, ground water and water ways. Moreover, they eventually lead to diseases to both humans and animals. Instead of directly dumping to the landfill these wastes could be diverted and converted to renewable energy using anaerobic digestion.

In this research, mixed vegetable wastes were anaerobically digested in a $1 \mathrm{~L}$ batch type laboratory scale reactor at atmospheric conditions with a hydraulic retention time of 20 days to determine their biomethane potential. Cow manure was used as inoculum. The results revealed that co-digestion of vegetable wastes and cow manure generates sufficient biogas/methane that could be utilized as renewable energy.
\end{abstract}

Keywords - vegetable wastes, anaerobic digestion, biogas, methane.

\section{INTRODUCTION}

Solid waste management remains a major challenge in the Philippines especially in urban areas like Metro Manila. Improper wastes disposal, inefficient wastes collection and lack of disposal facilities are among the dominant concerns in the country's solid waste management. Unless these are addressed, the wastes generated from various sources will continually lead to health hazards and serious environmental impacts such as ground and surface water contamination, flooding, air pollution and spread of diseases [1].

Vegetable wastes are produced in large quantities in markets and constitute a source of nuisance in municipal landfills because of their high biodegradability [2]. The amount of municipal solid waste (MSW) generated in Philippines is more than 40,000 tons per day and contains around $27 \%$ solid waste from commercial sources, which include commercial establishments and public/private markets. The easy biodegradable organic matter content of vegetables waste with high moisture facilitates their biological treatment and shows the trend of these wastes for anaerobic digestion [3].

Anaerobic digestion is a series of biological processes in which microorganisms break down biodegradable material in the absence of oxygen. One of the end products is biogas, which

Dennis E. Ganas, Assistant Professor, University of Science and Technology of Southern Philippines, Lapasan, Cagayan de Oro City, Philippines

Dr. Consorcio S. Namoco Jr, University of Science and Technology of Southern Philippines, Lapasan, Cagayan de Oro City, Philippines. is combusted to generate electricity and heat, or can be processed into renewable natural gas and transportation fuels. Anaerobic digestion is an attractive treatment of high strength organic wastes such as vegetable wastes, since it produces renewable energy, methane, and valuable digested residues, liquid fertilizer and soil conditioner [4].

Methane formation in anaerobic digestion involves four different steps: hydrolysis, acidogenesis, acetogenesis, and methanogenesis. The digestion process begins with bacterial hydrolysis of the input materials in order to break down insoluble organic polymers such as carbohydrates and make them available for other bacteria. Acidogenic bacteria then convert the sugars and amino acids into carbon dioxide, hydrogen, ammonia, and organic acids. Acetogenic bacteria then convert these resulting organic acids into acetic acid, along with additional ammonia, hydrogen, and carbon dioxide. Finally, methanogens convert these products to methane and carbon dioxide.

There are various factors affecting biogas production such as $\mathrm{pH}$, temperature, inhibitory parameters like high organic loading. Volatile solids input, digester temperature and retention time are operational parameter that have a strong effect on digester performance [5].

The objective of this study is to determine the biomethane potential of vegetable wastes commonly found in the Philippine markets mixed with cow manure as inoculum.

\section{MATERIALS AND METHODS}

\section{A. Feed characteristics}

The feed consisted of mixed vegetable wastes (eggplant, lady finger, squash, Chinese pechay, cabbage, pechay, pepper, radish, cucumber, tomato, bitter gourd, potato, carrot, sayote and lettuce) and were collected from the public markets in Cagayan de Oro City. These wastes were then manually chopped into smaller pieces for faster digestion. The total initial solid concentration of vegetable waste was $6.25 \%$, with a total volatile solids (VS) content of about $92 \%$, all performed according to APHA standards [6].

\section{B. Inoculum}

The inoculum used for this research was cow manure (CM) collected at Manresa Farm in Upper Carmen, Cagayan de Oro City. It was at least a day old and was not screened.

\section{Digester set-up}

The experiments were performed using 1.0L plastic 
containers as single-fed batch type digesters and were kept at atmospheric conditions for 20 days. Each digester contained 100 grams of mixed vegetable wastes (VW), 100 grams of inoculum and $300 \mathrm{~mL}$ water. The digesters were properly sealed to avoid any type of leakage. Each digester was manually mixed for 1 minute once a day by shaking and swirling. There are two sets for the inoculum-vegetable waste mixture: one set is initially 'treated' with alkalinity buffer of $1 \mathrm{~N}$ sodium bicarbonate $(\mathrm{NaHCO} 3)$ while the other set does not contain any buffer solution to serve as 'control'. Both sets of experiments were replicated twice to achieve a more accurate and consistent results.

\section{Analytical methods}

The temperature, $\mathrm{pH}$ and pressure of each digester were monitored daily using thermometer, $\mathrm{pH}$ meter and digital manometer respectively. The daily biogas production of each digester was determined using the water displacement method. The volume of water displaced from the bottle was equivalent to the volume of gas generated. Every five days biogas samples were collected to determine the methane concentration using a portable methane gas analyzer.

\section{RESULTS AND DISCUSSION}

\section{A. $p H$}

$\mathrm{pH}$ dropped substantially in the first few days due to high volatile fatty acids formation. This is evident especially to 'control' sets as $\mathrm{pH}$ dropped to as low as $5.0 \mathrm{pH}$ which inhibits methane formation. Direct addition of alkalinity in the form of bicarbonates was therefore necessary to maintain stable and acceptable values for alkalinity and $\mathrm{pH}$. Methanogenic bacteria work effectively at the $\mathrm{pH}$ range of 6.5 and 8 . Figure 1 shows the $\mathrm{pH}$ curve of both 'treated' and 'control' set ups.

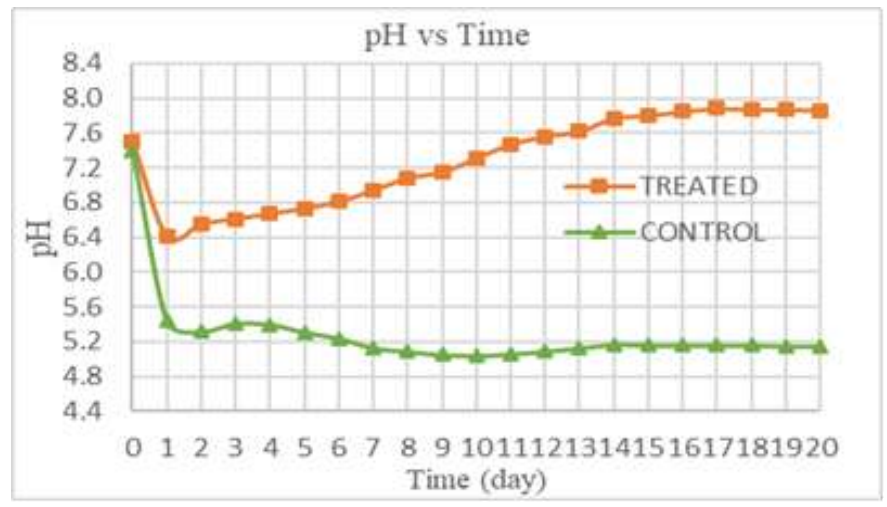

Fig. 1: $\mathrm{pH}$ curve.

\section{B. Biogas production}

Biogas was already produced during the first four days but it was mainly carbon dioxide (CO2) and hydrogen sulfide (H2S). On the 9th day the 'treated' mixture continued to produce more biogas even until the retention time of 20 days elapsed. Note that biogas production for 'treated' set may continue to increase until the subtrates are totally consumed. Figure 2 and 3 display the daily and cumulative biogas production, respectively.

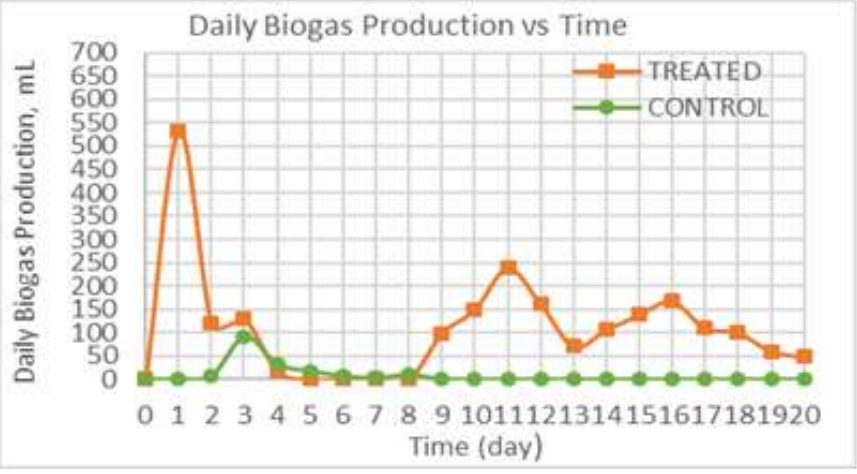

Fig. 2: Daily biogas production.

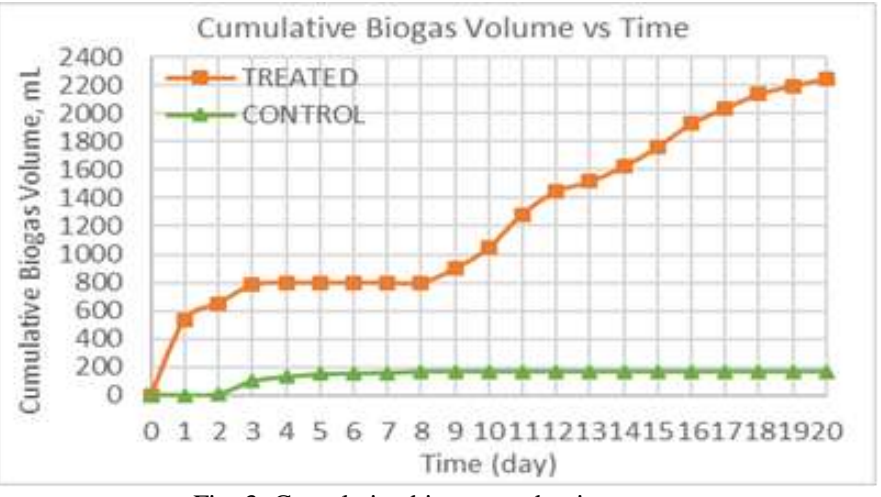

Fig. 3: Cumulative biogas production

\section{Methane content}

Methane concentration for the 'control' was unsurprisingly very low to nil because of the failure of methane-forming bacteria to convert the organic acids to methane. The $\mathrm{pH}$ was too low for the methanogens to survive. However, for treated slurries methane increased substantially and was able to achieve a methane concentration of more than 50\% which is enough to produce a 'blue' flame during the flame test as shown in Fig.5. Figure 4 graphs the methane concentration in the biogas. Note that the methane content may further increase as digestion continues.

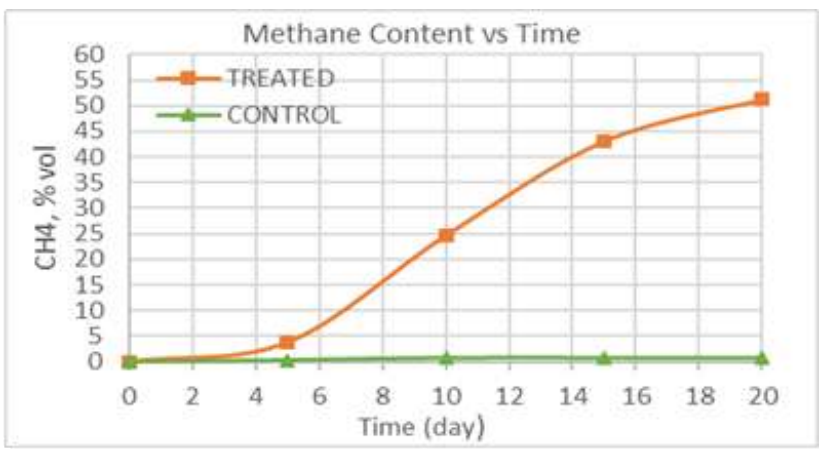

Fig. 4: Methane content. 


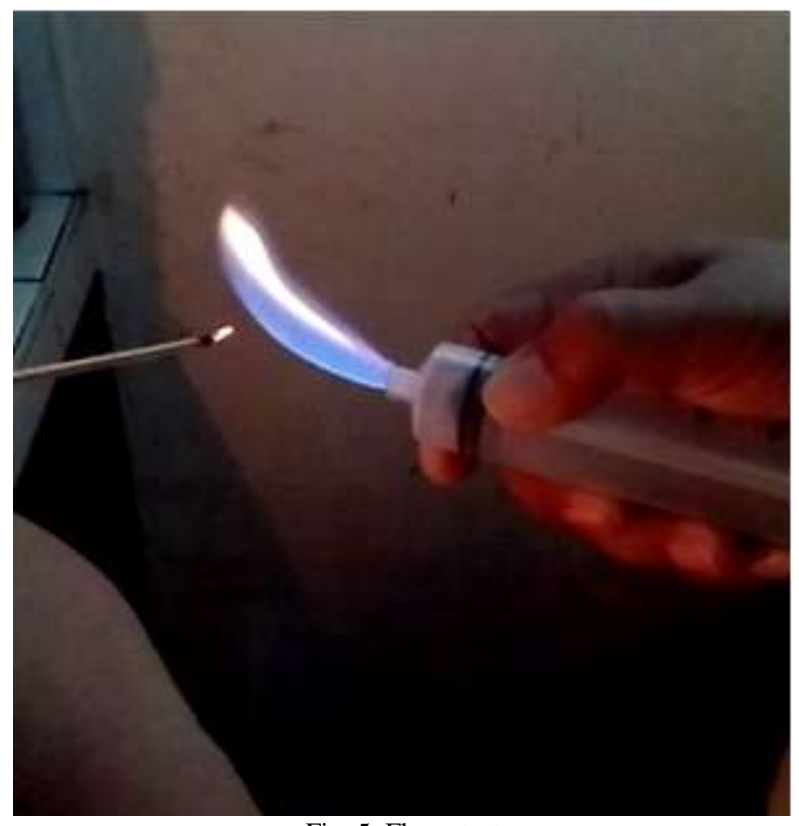

Fig. 5: Flame test

\section{ACKNOWLEDGMENT}

I would like to acknowledge the following people for their knowledge and support on this research: Dr. Eliseo P. Villanueva, Dr. Antonio Sami Magomnang and Dr. Leonel P. Pabilona.

\section{REFERENCES}

\section{(Periodical style)}

[1] retrieved https://www.senate.gov.ph/publications/SEPO/AAG_Philippine\%20Soli d\%20Wastes_Nov2017.pdf

[2] Viturtia A., Mata-Alvarez J., Cecchi F., Fazzini G., 1989, Two-phase anaerobic digestion of a mixture of fruit and vegetable wastes, Biological Wastes, 29, 189-199. https://doi.org/10.1016/0269-7483(89)90130-4

[3] Bouallagui H., Ben Cheikh R., Marouani L., Hamdi M., 2003, Mesophilic biogas production from fruit and vegetable waste in a tubular digester, Bioresource Technology, 86, 85-89. https://doi.org/10.1016/S0960-8524(02)00097-4

[4] Angelidaki and Ahring, 1994, Anaerobic thermophilic digestion of manure at different ammonia loads: Effect of temperature, Water Research, 28 (3), 727-731. https://doi.org/10.1016/0043-1354(94)90153-8

[5] Forster - Caneiro T. Perez, Romero L., 2008, Anaerobic digestion of municipal solid wastes: Dry thermophilic performance, Bioresource Technology, 99, 8180-8184. https://doi.org/10.1016/j.biortech.2008.03.021

[6] APHA,1998, Standard methods for the examination of water and wastewater, 20th edition, American Public Health Association, Washington DC. 